\title{
Recognition, Conflict and the Problem of Ethical Community
}

\author{
Shannon Brincat
}

Recognition has become a central theme in contemporary political, social, and international relations theory. Its fundamentality to social life appears almost selfevident given that how we recognise others and are recognized by others is fundamental to both the identity of individual subjects and the relations between self and other in ethical community. Recognition is something therefore central to political life also: nominally as a necessity in the formation of self-identity and something properly basic to relations between self and other, and expansively as a normative foundation for a theory of justice concerned with the mutual recognition of all members of society (individuals and groups), the actualization of their capacities, and respect of their identity.

It was Hegel who first situated recognition as essential for self-consciousness, indeed, he famously claimed that self-consciousness can exist only when recognized by another self-consciousness (Hegel, 1977: §178). In this way, recognition can be defined most simply as a relation between recogniser and recognisee, an intersubjective relation in which both agents place value in the recogniser as capable of recognition, and the recognisee as worthy of recognition (Ikäheimo, 2002: 453455). Recognition is both a responsive act, as in the recognition of pre-existing features of a subject or what it is to be recognized as a subject, and a generative notion that may confer specific characteristics or a certain status onto subjects. As such, recognition pertains to both individuals and groups/collectives and their respective identities, rights, and value. Literature in the social sciences has been weighted toward the former, which is hardly surprising given that Hegel's phenomenology of the struggle for recognition in the Master/Slave dialectic became increasingly concerned with the formation of individual subjectivities or wills, leading to Kojève's existential reading of this relation, something taken up further by Sartre and others that have since over-emphasised the individualized subject in processes of recognition (Kojève,1969: 7; Sartre 1956: 471-534). ${ }^{1}$ This is not to suggest, however, that group or collective recognition has not been accounted for. Hegel placed recognition as foundational to ethical life (Sittlichkeit) through formal expressions of right and in the ethical relations of the family, civil society and the state (Hegel, 1980; see Smith, 1989: 3-18). Similarly, Axel Honneth's discussion of successful struggles for recognition and the social practical and institutional forms of recognition in society (1995: Chapter 5), and Charles Taylor's defence of multiculturalism and communitarian ethics (1994: 25-73), clearly articulate with the fundamentality of recognition in group/collective relations.

Recent developments in the theory and politics of recognition since the mid1990s have been led by the pioneering work of both Taylor and Honneth, inspiring an ever-expanding list of supporting scholarship primarily focused on struggles for

\footnotetext{
${ }^{1}$ On this transition between Hegel's Jena Period and the Phenomenology see Honneth (1995).
} 
recognition within states and local communities. ${ }^{2}$ This has been met with a growing interest, particularly in recent years, regarding the question of recognition in international relations with many scholars now concentrating on processes of recognition between nation-states. ${ }^{3}$ What has yet remained under-theorised are processes of recognition that are not framed by or within the state, that is, recognition processes between different individuals and groups across, between and over the state (Brincat, 2013). Nevertheless, the primary thrust and analytical purchase of recognition theory is that it places intersubjectivity as key in ethical, socio-political life. This is far removed from the philosophy of the subject and atomistic/individualist doctrines that have dominated political philosophy in the modern period (see Macpherson, 2010), just as it offers an alternative to the most common theories of justice (i.e. distributive, procedural, retributive or restorative models). ${ }^{4}$ For recognition theory, such individualistic ontologies possess a socio-political naïvety, for rather than nominalism, atomism, or rational choice, recognition theory holds that the individual subject - in both their identity and the articulation of their freedom - is a social achievement, something that can be formed only though successful acts of recognition in society. Hegel, Taylor, and Honneth each show that intersubjectivity is a precondition for individual identity formation and, as such, look to the development of genuine subjectivity through, and with, others - or what Hegel cryptically referred to as “being with oneself in one’s other” (Hegel, 1980: §7A). At the ontological level - and why recognition is deemed, by some, to possess a universally emancipatory character - is because all humans are believed to require recognition as a "vital human need" (Taylor, 1994: 26) at both psychological and sociological levels for the stable construction of identity. For Honneth, there is an inherent interest in all individuals for recognition, as he claims: "the reason we should be interested in establishing a just social order is that it is only under these conditions that subjects can attain the most undamaged possible self-relation, and thus individual autonomy" (Fraser and Honneth, 2003: 259).

Offering one of the most systematic and fully developed accounts of a theory of recognition, Honneth explains its achievement through the tripartite social structures of recognition in 'love, rights and solidarity'. Here, subjects affirm essential aspects of their individual identity through three interrelated patterns of recognition, namely: self-confidence (in their primary relations through which subjects are socially recognised as the being of unique needs); self-respect (in society and formal relations where subjects are socially recognised as a person of equal responsibility and agency), and; self-esteem (in socio-cultural life where subjects are socially recognised as a bearer of something unique or something of social value). Expressed alternatively, it is through these social achievements that each individual is recognised in their neediness, their equality and agency, and their social contribution to society (Honneth, 2003: 170-1). While not presented in a systematic fashion as Honneth' theory, for Taylor, the centrality of recognition to identity is reflected in loving care,

\footnotetext{
${ }^{2}$ For some key examples see: Banting and Kymlicka (2001); Tully (2004: 84-106); Thompson (2006); Connolly, Leach and Walsh (2007); Van Den Brink and Owen (2007). For a general introduction to recognition theory see McQueen (2011).

${ }^{3}$ Wendt (2003: 491-542); Haacke (2005: 181-194); Heins (2005: 141-153); Kochi (2009); Lindemann and Ringmar (2012).

${ }^{4}$ Arguably, there is clear overlap will all four and recognition. However, recognition has been shown to articulate with a capabilities-based approach and be highly useful in a variety of contexts (see for example Schlosberg, 2012: 445-461).
} 
the politics for equal dignity and the politics of difference. While the first is not considered by Taylor as a matter of public contestation, the politics of equal dignity aims at the recognition of the common humanity in each individual. In contrast, the politics of difference focuses on the individual and specific uniqueness of each subject and group (1994: 37-39). While both hold an inherent universalism, it is the latter that is seen to be express and preserve the particular. However, Taylor suggests that what is considered equal dignity is defined by the dominant social group and is therefore a form of hegemony (1994: 66) and he implores us to be open towards other cultures and see in these traditions something valuable (1994: 68-71). Honneth offers a different interpretation, one that is widely regarded as being more positive, even optimistic (see Connolly 2010). For him, disrespect is the experiential content from which social struggles for recognition are formulated and which offer the potential for either an expansion of the circle of those recognized in society, or the qualities to be socially esteemed or valued (1995: 110, 121-122).

This draws us directly to the optimistic or pessimistic appraisal of recognition processes, a question that pivots on the emancipatory potential of mutual recognition or the potential for domination within the established forms of recognition within a given society. What is a matter of extreme contention is what can be best described as the regulative character of recognition: that is, does recognition serve to enable forms of self-identity, or does it restrict these to established social patterns? Is there some almost transcendental quality to struggles of recognition by which individuals and groups may push against the status quo - a normative 'surplus of validity', as Honneth calls it, that may bring about "an increase in the quality of social integration" (Fraser and Honneth, 2003: 184-185) - and which confirms an inherent emancipatory quality to recognition processes? Or is recognition a form of domination or cultural hegemony as circumscribed by the structures (institutional and cultural) of ethical life as it is?

On the pessimistic side of this debate, what is at stake is what Levinas would have called the danger of reducing the other to a recognized form in our own subjective terms, thus negating the other's absolute difference (1969). This problem can be traced as far back as the first articulation of the Master/Slave dialectic by Hegel in the System of Ethical Life where the relation is portrayed as a particular antagonism in which a "living individual confronts a living individual" and because their power (Potenz) is "unequal" "one is might or power over the other" (Hegel, 1979: 125). On this darkside of recognition, what is emphasised is the assimilationist tendencies within recognition that works on at least two levels: the individual psychological and social. The first as we have already been introduced to, where recognition takes place between two (or more) subjects and is regarded as a battle to dominant and normalize the other by reducing them to oneself. The second refers to the view of recognition as societal-wide form of hegemony that privileges certain subjectivities and excludes or denigrates others.

Along the lines of the first critique, Judith Butler views the primary relation that constitutes every self-identity to be exclusion. For her, the Hegelian "selfrecognitive model" violently internalizes the other as a unity with the ' $\mathrm{I}$ ' thus leading to a permanent separation of subjects (see esp. Butler, Laclua, Zizek, 2000: 172). This separation means that the Hegelian promise of mutual recognition is a false and unobtainable ideal. That is, Hegel's notion that recognition cannot remain one-sided 
(i.e. the domination of slave/Bondsman as a form of misrecognition) but must be transcended through genuine reciprocity, is a psychological impossibility for subjects. On a related point, Nancy Fraser has argued that because of the "excessively personalised" injury that constitutes disrespect and denigration, that rather than an emancipatory struggle for recognition the subject may actually internalize the shame or disrespect, thus negating any emancipatory potential under an overarching hegemony of established recognition patterns (2003: 204).

In terms of the second critique regarding socially situated forms of recognition, Althusserian interpellation would suggest that subjects may suffer preconscious definition of identity because they are caught within a fixed horizon of the forms of recognition that are socially possible. So too, Bourdeieu's notion of habitus suggests that we are framed by the forms of power through which the intersubjective relations of recognition take place. Any move beyond this social context of recognition would render the ideal of mutual recognition purely transcendental. Taking up this viewpoint in a sustained critique of recognition theory, Markell (2003) has posited that there is little space in either Taylor or Honneth's optimistic approaches for the individual to resist the dominant recognitive norms or institutionalised processes of one's ethical community. As such, demands for the recognition of one's identity are merely the reflection of the power and interests of status quo, rather than some authentic drive of selfhood towards actualisation. As shown by Butler, if forms of identity are governed by specific ethical norms, that is, processes and institutions that frame specific thought and actions in subjects, then there can be no ontology of identity but mere essentialised notions that are in fact exclusionary categories that cannot be used for solidarity (Butler, 1992: 14-15). These are what Connolly, Leach and Walsh describe as the "circumstances that may corrupt our need for recognition, producing desires for forms of recognition [and] may well function to reproduce social inequalities" (2007: 3).

In distinction to these pessimistic interpretations of the possibilities of recognition, what lies the center of optimistic readings is the potential for mutuality and struggle. In regards to the former, mutuality is typically depicted as the ideal outcome of the recognition process in which neither party dominates the other but is recognized freely and equally by, and as, a unique subject. Indeed, mutuality forms both the normative and explanatory core of the recognition theoretic. As Hegel stressed, recognition is "the double process of both self-consciousnesses... action from one side only would be useless, because what is to happen can only be brought about by means of both" (1977: 230-231). Without mutuality, recognition would be only partial, one-sided, and thereby not only radically incomplete but a form of misrecognition: an error that not only harms or disrespects the misrecognised subject but corresponds to a reduction in the possible freedom of the dominant subject. Mutuality, then, is nothing less than a "precondition for self-realization" (Anderson, in Honneth, 1995: $\mathrm{x}$ ) - and conversely "legitimate recognition is always mutual" (Tully, 2000: 474). This, in part, explains the 'vital necessity' of mutual recognition for all individuals and also its universally emancipatory quality for the social totality.

Borrowing from Honneth's framework once again, mutuality is premised as essential for each stage of stable identity formation, just as it is for the normative institutionalisation of a just and free social order. Initially, mutuality in the sphere of primary relations ('love') prepares the ground for the type of relationship-to-self of 
basic self-confidence that is considered "conceptually and genetically prior to every other form of reciprocal recognition" (Honneth, 1995: 107). Such individual selfconfidence is indispensable for autonomous participation in public life and is therefore the foundation for institutionalized order of 'rights' that secures mutual recognition in the negative sense of the formal equality of citizen-subjects, their agency and responsibility (on this see Hegel, 1979: 101-110; Hegel, 1980: Section One; Williams 1997, 59-68; Honneth, 1995: 92ff). In turn, the mutual esteem of the specific properties of individuals and groups serves to define the difference of each subject - their unique personality, interests and abilities - and to register these "goals and desires" as something of social contribution and worth (Honneth, 1995: 122, 169). However, there is contestation over what should count as an achievement or quality of social value (Honneth 1992, 126), and some have indicated the problematic nature of esteem that may intensify group competition and be inconsistent with egalitarianism (see McBridge, 2009).

Nevertheless, taken together, mutuality across these three social spheres is seen to eschew any lesser forms of 'mere' recognition and create institutions necessary for diversity and difference to flourish. As Taylor suggests, the politics of difference may secure the unique specificities and cultural features of all individuals and groups (1994: 37). Or as expressed by Appiah, through these social achievements can be secured the conditions for recognising someone as they really are (Appiah 1994: 149). Others, like Ricoeur, actually envision social change through a pure ethics of recognition (2005). It is this fundamental aspect of the Hegelian tradition of mutual recognition that offers the empirical basis for mediating the particular and universal in society, and thus offers a unique response to the vexatious question of ethical prioristing between insider/outsider or citizen/human - a relation that is typically portrayed in an antagonistic and exclusionary dualism (see Linklater, 1990; Walker, 1993). While this radical potentiality in recognition is perhaps expressed in an overly idealized rather than actualized manner, it is the second element of the optimistic interpretation - its focus on struggle - that gives it purchase on lived social relations that may bring mutuality about.

As explained simply by Tully, struggles for recognition are both a challenge to a prevailing rule or norm of intersubjective recognition and a demand for a new rule or norm, thereby altering in complex ways the unjust relation of power that these established rules/norms have legitimised (2000: 470). Such struggles are more than Hegel's encounter between two self-consciousnesses (Hegel, 1807: 232ff) but involve multilateral webs of relations (and their affect) throughout society (Tully, 2000: 474). In this context, to , to assert monological notions of identity is to overlook the intersubjective basis of the self and the social context of struggles for recognition. For Honneth, experiences of distorted recognition, disrespect or denigration generates or provides the impetus for new social struggles. That is, the violation of our moral expectation to be recognised, and the perception of such injustices of disrespect or denigration - that includes, but is not limited to, humiliation, degradation, insult, disenfranchisement and physical abuse (Anderson, in Honneth, 1995: viii) - provides Honneth with a model of social struggle towards the establishment of ideal processes of mutual recognition. Such experiences provide the motivational basis, the reasons and emotional responses, against distorted processes of recognition. However, this does not mean that such struggles will be successful or even take place - rather that this tension informs a dialectic in which the potential for the emergence of mutuality 
is ever-present. The actualization of mutuality is a contingent and political question of struggle and power. Optimism emerges from the belief that given the fundamentality of recognition for individual subjectivity and social flourishing, transgressions will spur political action. However, even Ricoeur who is perhaps the most optimist of all recognition theorists, admits that demands of recognition may never end and may indeed take the form of what Hegel called the 'unhappy consciousness' (2005: 218), in which the self remains alienated from others. As such, rather than a telos or endpoint, struggles for recognition are open-ended, or what Tully labels "continuous processes" (2000: 477).

Turning now to lived struggles, we can see that while these overlap with different socio-economic contexts and distributional demands (Fraser in Fraser and Honneth, 2003: 50-54), anticolonial and apartheid struggles, first wave feminism, the Civil Rights movement, and the international workers movement, can all be seen as unique forms of struggles for recognition. That is, they can be seen to share an affinity with the so-called struggles in the politics of difference or identity- i.e. ethnic, religious, LGBT, disabled and indigenous, to name some of the more prominent social struggles that seek to affirm recognition of the needs, equality and contribution of these individuals and groups. Even struggles between nation-states, while typically seen as mere instrumental conflicts for power, have been shown to include struggles for recognition, prestige, and honour (see Lindemann and Ringmar, 2012). As such, it is by mutuality and struggle that contemporary political struggles can not only be understood but also justified

This tension between pessimistic and optimistic accounts of recognition has been the guiding problematic animating this Special Issue of Global Discourse. While not aiming at resolution, Recognition, Conflict and the Problem of Ethical Community was based around exploring these themes in a truly transdisciplinary manner across social, political and international theory by examining recognition processes between individuals, groups, and states. The Special Issue canvasses a broad array of different research on recognition: from conceptual pieces as offered by Lindemann (2015a) and Ringmar's (2015a) contributions; to historical and practical examinations of recognition as advanced in Jaschob (2015) and Delori (2015); from policy prescriptions for foreign relations (Wolf, 2015), and recognition processes between individuals (Connolly, 2015); to pathologies of recognition in violent groups (Clément, 2015).

Recognition, Conflict and the Problem of Ethical Community begins with Julie Connolly's (2014) exploration of the phenomenology of shame in struggles for recognition. Connolly argues that without some kind of disclosure, the formulation of the relevant claim, the struggle for recognition cannot get started; and that without acknowledgement, recognition remains incomplete. This suggests a refinement of Axel Honneth's critical theory of social recognition that Connolly considers optimistic regarding the possibilities of the experience of misrecognition. For Connolly, things are not so straightforward regarding resolution through just institutional innovations. This is not only because recognition may fix identity, reproducing the limitations on agency via hegemonic social standards but because the lack of an emotional response may make it unlikely that the injustice will be exposed and solidarity formed in social struggles for recognition. Quite simply, Connolly suggests that not all struggles for recognition may be emancipatory. Turning to Agnes 
Heller and Martha Nussbaum, Connolly reveals in their work a more complex phenomenology of shame, guilt, and moral conscience that shows the need for mediation between ethics and negative feelings. Similarly, Toni Morrison's first novel The Bluest Eye (1999) depicts how the consequences of shame are difficult to predict and may have a destructive impact. The question for struggles for recognition is how solidarity can be formed through disclosure and acknowledgement rather than negative emotional power. Turning to Hannah Arendt, Connolly argues that the politics of recognition rests on the politics of disclosure and acknowledgement, through which we appear to each other and may problematise the very structure of interpretation of self-realization and human agency in society. Tony Castleman (2014) replies that the next step may be to explore what conditions, contexts, and other factors influence responses to these phenomena and to identify factors that influence agency and disclosure and acknowledgement processes.

Continuing with the critical interrogation of recognition theory, Maéva Clément (2014) examines the problem of misrecognition - those cases in which, far from an emancipatory change in social life towards mutuality, leads to discourses of supremacy and an increase in violence. Focusing on the radical Islamist group AlMuhajiroun (that operated from 1996 to 2004 principally within the UK), Clément explores the dynamics between the alleged experience of non-recognition of this group and the reorientation of the group's preferences towards violent practices. Viewing misrecognition as a mismatch between self-image and that reflected by others, groups facing denials of recognition can either accept demeaning/disrespectful images imposed by others, or they may challenge these. Clément shows that the representations with Al-Muhajiroun's discourses about the the 9/11 attacks and the war in Afghanistan orientated the group towards increased radicalism and violence. Specifically, as Al-Muhajiroun's worldview was rooted in prestige, seeking recognition as an Islamist group, the Islamic Emirate of Afghanistan, and the transnational community of Muslims or Ummah it was not concerned with contesting hegemony or domination, but wished to replace Western hegemony with an Islamic world state. Adopting a poststructuralist discursive epistemology, Clément analyses an array of Al-Muhajiroun's discourses showing the gradual transformation of the nature of its struggle for recognition, how it transfigured the West to a lesser subjectivity, disqualifying its capacity as intersubjective recognition partner. In turn, Al-Muhajiroun sought unilateral recognition of its dominance in a new hegemony, removing the case far from mutuality, but as Lee Jarvis (2014) notes in his reply, such radicalization has a particular history that needs to be acknowledged. That is, analysis should take into account how Al-Muhajiroun has been itself discursively constructed by other interested parties, thus opening up the reconstruction of the intentions/purposes behind discursive acts by asking why Al-Muhajiroun sought to construct its struggle as it did, and, deconstructing Al-Muhajiroun's struggle in its own terms.

Turning to international relations, Erik Ringmar's (2014a) groundbreaking article offers nothing less than an alternate history of the origins of international society. On the one had, he finds that international society was formed through practices of recognition that affirmed the similarities between European states, and, on the other, through practices of non-recognition that affirmed differences between Europeans and non-Europeans. This not only contradicts liberal and English School accounts of the historical narrative of world politics that remains deeply embedded in 
the disciplinary mainstream of international relations, but also the assumption of acculturation, the idea that international society was formed when a core of likeminded European states realized how much they had in common and extended this outward to other nations. As Ringmar shows through examples taken from diplomacy, trade, and warfare, and his case-study on cultural artifacts, international society was formed by sharp distinction drawn between Europeans and all others. That is, practices of mutual recognition amongst Europeans existed alongside practices of non-recognition for non-Europeans. Whereas European states enjoyed full sovereignty, 'savages' had no standing in international law and 'barbarians' were international subjects only in certain respects. Such practices of non-recognition established differences and inequalities into the very structure of international society: European states were made alike and non-Europeans were made different. The latter process was not some aberration but was constitutive of international society and continues to exist at the heart of the paradoxical nature of sovereignty, despite the rhetoric regarding equality and universal rights. For John M. Hobson (2014) this begs the question as to how we can move beyond this hierarchical Eurocentric conception of recognition, or indeed the very foundation of international society. For Hobson, if this is possible it must be to first recognize the mutually co-constitutive influences of East and West that have driven development of international society and, secondly, a process of mutual dialogue in which all peoples can sit down at the table of global humanity and mutually recognise each other.

Offering a practical engagement with status recognition in foreign relations, Reinhard Wolf (2014) formulates a ten-point policy recommendation aimed at facilitating international cooperation through respect and recognition. For Wolf, research has demonstrated that meeting claims for recognition can foster international understanding while status misrecognition can fuel conflict. So whilst international recognition is more nuanced and variable, its importance is acute. Respect increases the chances of cooperative behavior, allows for an open and thorough exchange of ideas, and helps avoid status conflicts. In turn, disrespect can aggravate ongoing conflicts, harm an actor's reputation, intensify resistance, incite resentment, and ruin prospects for long-term cooperation. Looking to demands for respectful treatment by China, Iran and India - who have experienced 'status mismatches' through colonial subjugation and other infringements by the West - Wolf offers clear examples of how calls for respect are not just a desire for better treatment but for moral consideration of the social importance and worth of these nation-states (including recognition of their ideas and values, physical needs and interests, achievements, efforts, qualities and virtues, and rights). Despite the modest costs of respect (time, materials, opening up to external influences, conflation, competition, and domestic standing), Wolf is resolute in his advice regarding how Western policies and gestures should convey greater respect and thus promote international progress, or at least minimize damaging effects of disrespect. Along similar lines Michael Clarke (2014) views respect as a cognate of honour, highlighting the benefits of Wolf's approach in conceiving recognition as a socially constituted and dynamic factor shaping international relations. However, Clarke also notes the problems presented by those situations in which parties in conflict may have irreconcilable interests and contradictory status-oriented goals.

Thomas Lindemann's conceptual essay (2014a) makes the strong claim that behind conflict and war always lies hidden conceptions of non-recognition between 
self and other. This thesis forms part of a larger research project on non-recognition, war, and the 'minimization of the other' as a motivation for conflict - an approach that contends with the far more popular explanations for war as based on security, power, or profit. For Lindeman, by contrast, conflicts arise when the self holds minimized presentations of the other and it is tension that forms the basis - or condition of possibility - for wars of interest. That is, wars for 'cold interests' are only possible when emotions of compassion are neutralized by the non-recognition of the other. Lindeman offers compelling empirical evidence that even wars most commonly interpreted in terms of material interest actually entail a 'minimizing' or non-recognition of the other. When the other is perceived as a threat, or as inanimate, or at an effective distance, the propensity for violence is increased by justifying war and paralyzing compassion. However, the claim that material interests can only lead to war if the other is minimized (or misrecognized), is queried by Brent J. Steele (2014) on epistemic grounds. Steele asks how can we have knowledge of such a process as necessary, suggesting that conflict may not occur only when correct recognition is negated or in error, but where one recognizes the other but seeks to destroy it.

Turning to history, Lena Jaschob (2014) provides an account of the impact of disrespect and non-recogntion through an analysis of Anglo-German interactions during the Anglo-Boer War (1899-1901). For Jaschob, respect can be seen as the adequate recognition of one's subjectively deserved status and yet such status, unlike material capablities, cannot be gained unilaterally. Consequently, a status mismatch can occur when an other party does not express or reflect this status through practicies of respect adequately, increasing the antagonism and potentially leading to serious conflict (Wolf, 2011). Jaschob finds that the Anglo-German relationship was characterized by misunderstandings, feelings of non-recognition, and disrespectful behavior on both sides. Focusing on the political consequences of the 'BundesrathAffäre', Jaschob argues that while the diplomatic crisis was quickly resolved, the underlying perceptions of disrespect and non-recognition had a persistent and negative effect on the Anglo-German relationship. Moreover, it was these subjective experiences that dominanted the political actions on the German side who sought compensations, both symbolically and materially. The desire for respect even overshadowed power-political interests that are typically seen as most important in conflicts regarding competing foreign policy objectives, a finding complementary to Lindemann's argument (2015). Jaschob thereby highlights the importance of status as a structural phenomenon in the international system, typically dowplayed in classical accounts of international relations and realpolitik. This signifies that a greater concern with practices of recogntion may help explain - and indeed mediate - foreign relations. Jaschob provides rich and detailed historical account of the ensuing diplomatic and relational crisis, and the residual status mismatch, between the German Kaiserreich and Great Britain remained. In the long-run, burdened by these incidents, the Anglo-German relationship would threaten the entire system. Bill Nasson (2014) replies however, that this cries was only one flashpoint in many over mutually respectful recognition between Germany and Britain. While he agrees that status-seeking left simmering attitudes that infected the relationship, this should not be pressed too far as not only were there still unilateral material considerations at play, but the UK was ascendant in the region and globally, and Germany was seeking to revise this order. As such, it is important to not lose sight of the convergence of 
political, strategic and economic imperatives alongside these status or recognitive dimensions of struggle.

Concluding the Special Issue, Mathias Delori (2014) offers sociological and ethnographic insights into the processes of recognition in contemporary Western wars through a case-study of French pilots who participated in the war in Libya in 2011. Delori's empirical work provides a unique engagement with the conceptual aspect of recognition and killing, an unsavoury subject areas rarely engaged. For Delori, military consent for killing is mediated by powerful discursive structures that frame those lives that are recognized as livable and those excluded from the ethics of compassion. He goes further however, by finding from his interviews with forty French pilots/soldiers that those killed were "ungrievable lives" (Butler 2010: xix), signifying a spectacular case of misrecognition - a phenomena he suggests that may increase in the context of contemporary humanitarian and technological wars. This contests sharply with those that see in modern technologies of war not the reification and dehumanisation of the enemy, but a trend toward human representation, resulting in a greater control of violence and decrease in number of people killed. Given this highly contested area, Delori's empirical research offers some insights that into how ideas and materialities co-constitutes each other in the discourse of wars that are inseparable from power. He shows that both the pilots and the vast majority of media outlets reporting on the conflict had no account of the number of Libyan loyalist combatants killed in their bombing runs, or the conflict as a whole. Even in the pilot's celebration of their missions, the enemy remained complexly absent. Both of these seem to confirm Delori's thesis that misrecognition has contributed to the ideational framing of humanitarian war on the one hand, and new technologies on the other, into a discourse in which some lives have become invisible and ungrievable. Kamil Shah (2014) responds however, that such contemporary Western wars have been built upon the incredible insecurity of the West whose list of perceived threats and enemies has only proliferated. The war in Libya was buttressed by discourses of humanitarianism but also invoked the Responsibility to Protect, conflating the West with the international community and privileging its discourses on humanitarian and military intervention to decide who could live or die.

Finally, we have two Review Symposium on seminal texts focused on recognition in international relations and social theory, respectively. The first engages with Lindemann and Ringmar's edited volume The International Politics of Recognition (2012). This book contains a number of chapters that apply recognition to the problems of international conflict, offering an alternative to mainstream approaches in international relations and security studies. Providing reviews are Zuo (2014), Duncombe (2015) and Olsson (2014) with individual responses from both Lindemann (2014b) and Ringmar (2014b). The second is Axel Honneth's The I in We (2012), a collection of essays that develop Honneth's theory of recognition in terms of a theory of justice, social reproduction, and individual identity formation. Reviews are given by Weber (2014), Murray (2014), and Heins (2014) and a detailed response is provided by Honneth (2014).

In closing, I would like to sincerely thank the author's who participated in the Review Symposia, Axel Honneth, Thomas Lindemann, and Eric Ringmar, and those reviewers who offered an array of critical viewpoints on these texts. I would also like to thank all of the author's in Special Issue for their rich and thought-provoking 
articles and who have offered a genuinely transdisciplinary engagement with the problem of recognition, violence and ethical community. Finally, a special mention of gratitude must be given to both the anonymous referees and those reviewer's who wrote replies to the articles and who make this journal unique.

Shannon Brincat, July 2014.

\section{References}

Banting, Keith. Will Kymlicka. (2001) Multiculturalism and the Welfare State: Recognition and Redistribution in Contemporary Democracies, Oxford: Oxford University Press.

Brincat, Shannon. (2013) “Cosmopolitanism: The Fourth Dimension of Recognition?”, presented at the International Studies Association (ISA) Annual Convention, San Francisco, 2-6 April, 2013

Butler, Judith. Ernesto Laclau, Slavoj Zizek. (2000) Contingency, Hegemony, Universality, London: Verso.

Butler, Judith. (1992) "Contingent Foundations: Feminism and the Question of "Postmodernism”'. Feminists Theorize the Political (Butler, Judith and Joan W. Scott Eds.), London: Routledge.

Butler, Judith. (2010) Frames of War. When is Life Grievable? London: Verso.

Castleman, Tony. (2014) “Reply to Connolly,” Global Discourse, 4(4).

Clarke, Michael. (2014) "Reply to Wolf” Global Discourse, 4(4).

Clément, Maéva. (2014) "Al-Muhajiroun in the UK: The Role of International Non-Recognition in Heightened Radicalization Dynamics," Global Discourse, 4(4).

Connolly, Julie. (2014) "Shame and Recognition: the politics of disclosure and acknowledgement," Global Discourse, 4(4).

Connolly, Julie. (2010) “Recognition and the Politics of Disclosure” (unpublished)

Connolly, Julie. Michael Leach, Lucas Walsh (Eds.) (2007) Recognition in Politics: Theory, Policy and Practice, Newcastle: Cambridge Scholars Publishing.

Delori, Matthias. (2014) "Killing Without Hatred: The Politics Of (Non)-Recognition In Contemporary Western Wars,” Global Discourse, 4(4).

Duncombe, Constance. (2014) "Review Symposium - Non-Recognition in International Relations: Developing New Approaches to Political Problems," Global Discourse, 4(4).

Fraser, Nancy. Axel Honneth. (2003) Redistribution or Recognition? A Political-Philosophical Exchange, London: Verso.

Haacke, Jürgen. (2005) "The Frankfurt School and International Relations: on the centrality of recognition”, Review of International Studies, 31(1): 181-194.

Hegel, G.W.F. (1977) Phenomenology of Spirit. (A. V. Miller. Trans.), Oxford: Oxford University Press.

Hegel, G.W.F. (1980) The Philosophy of Right, trans. T. M. Knox, New York: Oxford University Press.

Hegel, G.W.F. (1979) System of Ethical Life, T.M. Knox (Ed. And Trans.), Albany: SUNY. 
Heins, Volker. (2005) "Realising Honneth: redistribution, recognition, and global justice”, Journal of Global Ethics, 4(2):141-153.

Heins, Volker M. (2014) “Review Symposium - Survival through recognition?,” Global Discourse, 4(4).

Hobson, John. (2014) “Reply to Ringmar,” Global Discourse, 4(4).

Honneth, Axel. (1995) The Struggle for Recognition, Cambridge, MA: MIT Press.

Honneth, Axel (2014). “Rejoinder,” Global Discourse, 4(4).

Ikäheimo, Heikki. (2002) 'On the Genus and Species of Recognition.’ Inquiry, 45(4): 447-462.

Jaschob, Lena. (2014) “ (Dis-)respect and (Non-)recognition in World Politics: The Anglo-Boer War and German Policy at the Turn of the 19th/20th Century,” Global Discourse, 4(4).

Jarvis, Lee. (2014) “Reply to Clément,” Global Discourse, 4(4).

Kochi, Tarik. (2009) The Other's War: recognition and the violence of ethics, Abingdon: Birkbeck law Press.

Kojève, A. (1969) Introduction to the Reading of Hegel: Lectures on the "Phenomenology of Spirit" (A. Bloom, Ed., and J.H. Nichols, Trans.) New York, NY: Basic Books.

Levinas, Emmanuel. Totality and Infinity: An Essay on Exteriority. Pittsburgh: Duquesne University Press, 1969.

Lindemann, Thomas. Erik Ringmar (Eds.). (2012) The International Politics of Recognition, Boulder, CO: Paradigm Publishers.

Lindemann, Thomas. (2014a) "Interest, passion, (non)recognition and wars: a conceptual essay," Global Discourse, 4(4).

Lindemann, Thomas. (2014b) "Review Symposium - Recognizing (mis)recognition from the inside and the outside. Some criteria for "seizing” a slippery concept," Global Discourse, 4(4).

Linklater, Andrew. (1990) Men And Citizens In The Theory Of International Relations, $2^{\text {nd }}$ Edition, MacMillan Press, London.

Macpherson, Crawford B. (2010) The Political Theory of Possessive Individualism, Oxford: Oxford University Press.

Markell, Patchen. (2003) Bound by Recognition, Princeton, NJ: Princeton University Press.

McBride, Cillian. (2009) ‘Demanding Recognition: Equality, Respect, and Esteem’. European Journal of Political Theory 8(1): 96-108

McQueen, Paddy. (2011) “Social and Political Recognition”, Internet Encyclopedia of Philosophy. Available at: http://www.iep.utm.edu/recog_sp/. Accessed on 20 July, 2014.

Morrison, Toni. (1999) The Bluest Eye Vintage: London.

Murray, Michelle. (2014) "Review Symposium - Differentiating Recognition in International Politics,” Global Discourse, 4(4).

Nasson, Bill. (2014) “Reply to Jaschob,” Global Discourse, 4(4). 
Olsson, Christian. (2014) "Review Symposium - Warfare and Recognition in IR: On the potential inputs of the historical sociology of the state," Global Discourse, 4(4).

Ricoeur, Paul. (2005) The Course of Recognition.Translated by David Pellauer. Cambridge, MA: Harvard University Press.

Ringmar, Erik. (2014a) “Recognition and the Origins of International Society,” Global Discourse, 4(4).

Ringmar, Erik. (2014b) "Review Symposium - On the Reality of Mental Constructs,” Global Discourse, 4(4).

Sartre, Jean Paul. (1956) Being and Nothingness, London: Philosophical Library.

Schlosberg, David. (2012) “Climate Justice and Capabilities: A Framework for Adaptation Policy”, Ethics \& International Affairs 26(4): 445-461.

Smith, Stephen B. Smith. (1989) “What is 'Right' in Hegel's Philosophy of Right?”, The American Political Science Review, 83(1): 3-18.

Shah, Kamil. (2014) “Reply to Delori,” Global Discourse, 4(4).

Steele, Brent J. (2014) “Reply to Lindeman,” Global Discourse, 4(4).

Taylor, Charles. 'The Politics of Recognition'. Multiculturalism: Examining the Politics of Recognition. Ed. Amy Gutmann. Princeton: Princeton University Press. 1994: 25-73

Thompson, S. (2006) The Political Theory of Recognition: A Critical Introduction, Cambridge: Polity Press.

Tully, James. (2000) “Struggles over Recognition and Distribution,” Constellations, 7(4): 469-482.

Tully, James. (2004) “Recognition and Dialogue: The Emergence of a New Field”, Critical Review of International Social and Political Philosophy 7(3): 84-106.

Van den Brink, Bert. David Owen. (2007) Recognition and Power, Cambridge: Cambridge University Press.

Walker, R.B.J. (1993) Inside/Outside, Cambridge: Cambridge University Press.

Weber, Martin. (2014) "Review Symposium - Pushing the constellations of recognition,” Global Discourse, 4(4).

Wendt, Alexander. (2003) "Why a World State is Inevitable" European Journal of International Relations, 9(4): 491-542).

Williams, R. R. (1997) Hegel's Ethics of Recognition, Berkeley: University of California Press.

Wolf, Reinhard. (2011) "Respect and disrespect in international politics: the significance of status recognition,” International Theory 3(1) 105-142.

Wolf, Reinhard. (2014) "Treating Asian Nations with Respect: Promises and Pitfalls of Status Recognition,” Global Discourse, 4(4).

Zuo, Yana. (2014) "Review Symposium - On the Empirical Study of International Recognition,” Global Discourse, 4(4). 